\title{
Effect of summer season on milk protein fractions in Holstein cows
}

\author{
U. Bernabucci, ${ }^{, 1}$ L. Basiricò, ${ }^{*}$ P. Morera, ${ }^{*}$ D. Dipasquale, ${ }^{*}$ A. Vitali, ${ }^{*}$ F. Piccioli Cappelli,† and L. Calamari† \\ *Dipartimento di scienze e tecnologie per l'Agricoltura, le Foreste, la Natura e l'Energia (DAFNE), Università degli Studi della Tuscia, \\ via S. Camillo De Lellis, s.n.c, 01100 Viterbo, Italy \\ †Istituto di Zootecnica, Università Cattolica del Sacro Cuore, Via Emilia Parmense, 84, 29122 Piacenza, Italy
}

\section{ABSTRACT}

Milk characteristics are affected by heat stress, but very little information is available on changes of milk protein fractions and their relationship with cheesemaking properties of milk. The main objective of the study was to evaluate the effect of hot season on milk protein fractions and cheesemaking properties of milk for Grana Padano cheese production. The study was carried out in a dairy farm with a cheese factory for transforming the milk to Grana Padano cheese. The study was carried out from June 2012 to May 2013. Temperature and relative humidity of the inside barn were recorded daily during the study period using 8 electronic data loggers programmed to record every $30 \mathrm{~min}$. Constant managerial conditions were maintained during the experimental periods. During the experimental period, feed and diet characteristics, milk yield, and milk characteristics were recorded in summer (from June 29 to July 27, 2012), winter (from January 25 to March 8, 2013), and spring (from May 17 to May 31, 2013). Milk yield was recorded and individual milk samples were taken from 25 cows selected in each season during the p.m. milking. Content of fat, proteins, caseins $(\mathrm{CN})$, lactose and somatic cell count (SCC), titratable acidity, and milk rennet coagulation properties were determined on fresh samples. Milk protein fraction concentrations were determined by the sodium dodecyl sulfate-PAGE. Data were tested for nonnormality by the Shapiro-Wilk test. In case of nonnormality, parameters were normalized by $\log$ or exponential transformation. The data were analyzed with repeated measures ANOVA using a mixed model procedure. For all the main milk components (fat, protein, total solids, and solids-not-fat), the lowest values were observed in the summer and the greatest values were observed in the winter. Casein fractions, with the exception of $\gamma-\mathrm{CN}$, showed the lowest values in the summer and the greatest values in the winter. The content of IgG and serum albumin was greater in summer than in the winter and spring. A mild effect of

Received August 26, 2014.

Accepted November 15, 2014

${ }^{1}$ Corresponding author: bernab@unitus.it season was observed for milk SCC, with greater values in summer than in the winter and spring. A worsening of milk coagulation properties was observed in summer season. The alteration of cheesemaking properties during hot season seems strictly linked with changes of milk protein fractions mainly with the decrease of $\alpha_{S^{-}}$ $\mathrm{CN}$ and $\beta-\mathrm{CN}$ and the increase of undefined proteins.

Key words: heat stress, dairy cow, milk protein, casein fraction, whey protein

\section{INTRODUCTION}

Climate change is likely to be one of the main challenges that humankind faces during the current century. The increasing concern with the thermal comfort of agricultural animals is justifiable not only for countries occupying tropical zones, but also for nations in temperate zones where high ambient temperatures are becoming an issue (Nardone et al., 2010). Earth's climate has warmed in the last century (IPCC, 2007) and is predicted to continually change at rates unprecedented in recent human history [IPCC, 2007, Fourth Assessment Report (AR4)]. In our recent study (Segnalini et al., 2013), we demonstrated a gradual increase of both annual and seasonal temperature-humidity index (THI) during the period under investigation and a strong heterogeneity of the Mediterranean area. In particular, the analysis indicated that Spain, southern France, and Italy should be expected to undergo the highest THI increase, which in the last decade under study (2041-2050) will range between 3 and 4 units. During the summer months, the area presents characteristics indicating risk of thermal (heat) stress for farm animals.

We have to expect that the livestock systems (based on grazing, the mixed farming systems, or industrialized system) will be more and more negatively affected by climate changes (namely global warming). In addition, genetic improvement programs, which enhance production traits, may increase an animal's susceptibility to high environmental temperatures (Bernabucci et al., 2014) due to the close relationship between metabolic heat generation and production level (Kadzere et al., 2002). 
In addition to thermal effects on production, the quality of animal products is strongly and negatively affected by a hot environment. This is more important for high-quality products such as protected designation of origin (PDO) cheeses.

Milk characteristics are strongly affected by heat stress (Bernabucci et al., 2010). During hot season, a worsening of the main cheesemaking properties is observed (Calamari and Mariani, 1998); in particular, the reduction of the titratable acidity and the worsening of milk coagulation properties (MCP) make milk less suitable for the production of hard cheese with a long ripening time (Calamari and Mariani, 1998; Malacarne et al., 2005). Among the milk characteristics affecting the MCP, CN content and the CN composition are 2 important factors (Bertoni et al., 2001, 2005). Little information is available concerning changes of milk protein fractions (Bernabucci et al., 2002) and the relationship with cheesemaking properties of milk under heat stress conditions. Therefore, the study was aimed at evaluating the effect of hot season on milk protein fractions and cheesemaking properties of milk for Grana Padano cheese production.

\section{MATERIALS AND METHODS}

\section{Animals and Management}

The research protocol and the animal care were in accordance with the Directive 2010/63/EU of the European Parliament and of the Council of September 22, 2010 , on the protection of animals used for scientific purposes.

The study was carried-out in a dairy farm of 600 Italian Holstein lactating cows located near Brescia, Italy $\left(45^{\circ} 54^{\prime} \mathrm{N}, 9^{\circ} 93^{\prime} \mathrm{E}\right.$; altitude $148 \mathrm{~m}$ above sea level). The milk yielded in this herd is used to produce Grana Padano cheese. A cheese factory is present at the farm to transform the milk in this PDO cheese. The lactating cows were raised in a free stall barn equipped with axial flow fans and sprinklers in the feeding area and in the holding pen. Sprinklers were placed perpendicular to the airflow of the fans along the feed alley. Fans and sprinklers were thermostatically controlled: fans were switched on at $23^{\circ} \mathrm{C}$ and sprinklers at $27^{\circ} \mathrm{C}$ (soaking for $1 \mathrm{~min}$ and ventilation for $5 \mathrm{~min}$ ).
Cows were milked twice daily (0300 and $1500 \mathrm{~h}$ ) and milk yield (MY) at each milking was recorded electronically using Afimilk meters (S.A.E. Afikim, Israel). Cows were fed using TMR technique once daily ad libitum at $0830 \mathrm{~h}$. To ensure cows had ad libitum access to the TMR, the amount offered was assessed on a daily basis with the aim of producing from 3 to $8 \%$ refusal.

Constant managerial conditions (operators, similar batches of feed, milking frequency, and working routine) were maintained thorough the experimental period.

The study was carried out from June 2012 to May 2013. Measurements on microclimatic conditions, feed and diets, MY, and milk characteristics were carried out in summer (from June 29 to July 27, 2012), winter (from January 25 to March 8, 2013), and spring (from May 17 to May 31, 2013). The individual milk samples were taken from 25 cows selected in each season (5 measurements in summer, 2 in winter, and 2 in spring). The selected cows were balanced for parity, DIM, and MY (Table 1). The selected cows were hosted in 2 pens in each season.

\section{Measurements and Analyses}

Microclimatic Conditions. Temperature and relative humidity of the inside barn were recorded daily during the study period using 8 electronic probes connected to a data logger (Mini Data Logger 174-H, Testo, Milano, Italy) programmed to record every 30 min. Mean daily temperature and humidity and daily minimum and maximum temperature and humidity were calculated from temperature and relative humidity data recorded throughout the study. Data were used to compute a composite climatic welfare index, the THI, according to the formula of Kelly and Bond, as reported by Ingraham et al. (1979). The formula was

$$
\begin{gathered}
\mathrm{THI}=(1.8 \cdot \mathrm{AT}+32)-(0.55-0.55 \cdot \mathrm{RH}) . \\
{[(1.8 \cdot \mathrm{AT}+32)-58],}
\end{gathered}
$$

where AT was the ambient temperature expressed as degrees Celsius, and $\mathrm{RH}$ was the relative humidity expressed as fraction of the unit. Mean daily THI, daily minimum THI, and daily maximum THI were also calculated throughout the study.

\begin{tabular}{|c|c|c|c|}
\hline Item & Winter & Spring & Summer \\
\hline No. of animals & 25 & 25 & 25 \\
\hline Parity & $2.5 \pm 0.6$ & $2.5 \pm 0.5$ & $2.5 \pm 0.4$ \\
\hline DIM & $124 \pm 23$ & $129 \pm 22$ & $125 \pm 27$ \\
\hline Milk yield, L.animal ${ }^{-1}$ per d & $39.7 \pm 6.5$ & $39.8 \pm 10.2$ & $39.2 \pm 6.8$ \\
\hline
\end{tabular}

Table 1. Number of cows and overall mean $( \pm \mathrm{SD})$ of some characteristics of the groups involved in the study 
Feeds and Diets. Representative samples of TMR were collected at each sampling day around $0930 \mathrm{~h}$. Chemical composition (moisture, CP, crude fiber, NDF, starch, and ash) was determined using standard procedures. The chemical and nutritive characteristics of the diets were calculated at each sampling day.

Milk. At each sampling point, during the p.m. milking, MY was measured and representative individual samples were collected (MM85 with milk sampler, S.A.E. Afikim) from each cow. Fat, protein, CN, lactose contents, and titratable acidity were determined on fresh samples by the Fourier Transform Infrared Spectroscopy (FT 120, Foss Electric, Hillerød, Denmark). Somatic cell count was determined by an optofluorometric method on fresh samples (Fossomatic 180, Foss Electric). Furthermore, milk rennet coagulation properties were assessed as rennet coagulation time (RCT), curd firming rate $\left(\mathbf{k}_{\mathbf{2 0}}\right)$, and curd firmness $\left(\mathbf{a}_{\mathbf{3 0}}\right)$, using Formagraph (Foss Electric) on fresh samples. Briefly, $10 \mathrm{~mL}$ of milk was heated to $35^{\circ} \mathrm{C}$, and $200 \mu \mathrm{L}$ of rennet (Hansen standard 160 with $80 \%$ chymosin and $20 \%$ pepsin, Pacovis Amrein AG, Bern, Switzerland) diluted to $1.6 \%$ (wt/wt) in distilled water was added to milk at the start of the analysis to obtain 0.051 IMCU (international milk clotting units $\cdot \mathrm{mL}^{-1}$ ). Milk samples with RCT that did not coagulate after 31 min were classified as bad reactivity, and milk samples with RCT longer than 27 min were classified with scarce reactivity. Milk samples with RCT between 10.3 and 19 min were classified as samples having good coagulation properties.

Milk protein fraction concentrations were determined by SDS-PAGE performed according to Giacinti et al. (2013) on $12.5 \%$ slab gel (Figure 1). The fractions of milk proteins were diluted by adding an equal volume of double-concentrated sample buffer (125 mM Tris$\mathrm{HCl}, \mathrm{pH} 6.8,4 \%$ SDS, $0.8 M$ dithiothreitol, $0.4 \%$ bromophenol blue, and $20 \%$ glycerol) and heated at $100^{\circ} \mathrm{C}$ for $3 \mathrm{~min}$, to thermally denature proteins and to promote interactions of the proteins with SDS. Low molecular weight standards (Bio-Rad Laboratories, Watford, UK) were prepared in sample buffer. The electrophoresis was performed in a Mini-Protean III dual slab cell (Bio-Rad). Electrophoresis was performed at room temperature $\left(\approx 22^{\circ} \mathrm{C}\right)$ using a voltage stepped procedure: voltage was kept constant $(30 \mathrm{~V})$ until the samples completely left the stacking gel and then the voltage was increased $15 \mathrm{~V}$ per min for 4 times. Voltage was maintained constant $(90-100 \mathrm{~V})$ until the tracking dye reached the bottom of the gel. Immediately after ending electrophoresis, gels were removed from the plates and placed in a staining solution containing $40 \%$ methanol, $10 \%$ acetic acid, and $0.1 \%$ Coomassie Brilliant Blue R-250. Gels were left for $30 \mathrm{~min}$ in the

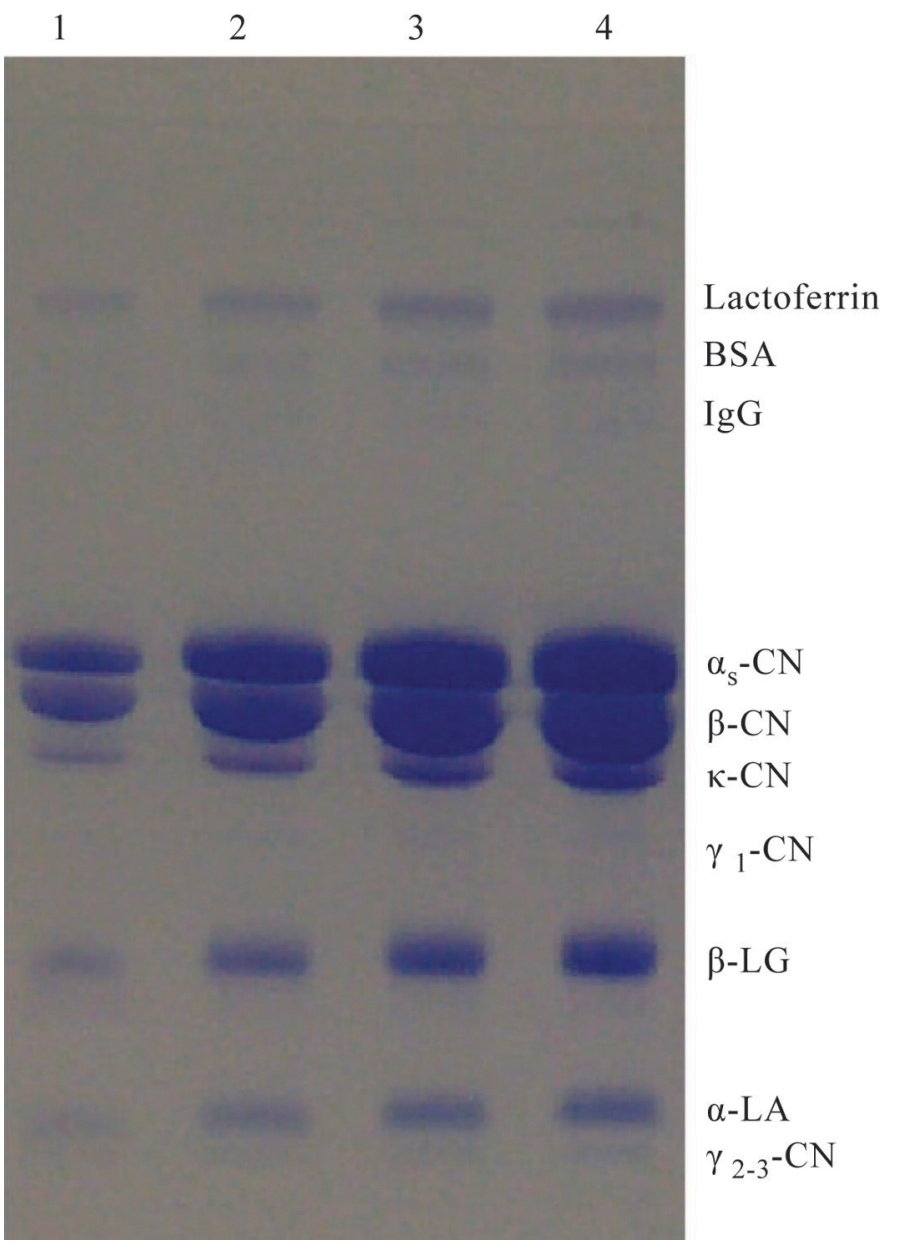

Figure 1. Representative SDS-PAGE profile of milk separated on $12.5 \%$ SDS-polyacrylamide gel and stained with Coomassie Brilliant Blue. Lanes 1 to 4: milk samples at different dilutions. Color version available online.

staining solution and then destained in the methanol/ acetic acid solution ( $5 \%$ methanol, $7 \%$ acetic acid).

Quantitative analysis of electrophoretically separated proteins was done by densitometry using BSA (Sigma, Milano, Italy) as internal standard, with Kodak EDAS290 densitometer and analyzed with ID Image Analysis software (Kodak Company, Rochester, NY). Detected polypeptides were identified using the standards BSA, lactoferrin, $\alpha-\mathrm{LA}, \beta-\mathrm{LG}, \kappa-\mathrm{CN}, \alpha-\mathrm{CN}\left(\alpha_{S^{-}} \mathrm{CN}\right)$, and $\beta-\mathrm{CN}$ (Sigma, Milan, Italy). All protein fractions were expressed as grams.liter ${ }^{-1}$; furthermore, CN fractions were also expressed as percentage of total CN.

\section{Statistical Analysis}

All statistical analyses were performed using the statistical software package SAS 9.2 (SAS Inst. Inc., Cary, NC). Data were tested for nonnormality by the 
Shapiro-Wilk test. In case of nonnormality, parameters were normalized by log or exponential transformation. The data were analyzed with repeated measures ANOVA using a mixed model (MIXED procedure of SAS). The model included the fixed effect of season (winter, spring, and summer), pen (2 levels), and the effect of sampling day, and individual variability (within cow $\times$ season). The analysis was carried out using 3 covariance structures: autoregressive order, compound symmetry, and spatial power structure. These were ranked according to their Akaike and Schwarz Bayesian information criterion, with the one having the least information criterion being eventually chosen. For each treatment, least squares means were computed, and pairwise comparisons (PDIFF option of SAS) were conducted when the $F$-test of one of the season factors was significant at $P<0.10$. Statistical significance was designated as $P<0.05$, and tendencies were declared at $P<0.10$. The statistical analysis of protein fractions was also performed including the logarithm of SCC as a covariate in the statistical model described before.

Pearson correlations among milk variables were calculated using the CORR procedure of SAS. Furthermore, milk variables were processed by principal components (PC) analysis of SAS.

\section{RESULTS}

The changes of THI observed during the trial are shown in Figure 2. Summer season was characterized by elevated daily THI. In our previously study, carried out in Italian dairy cows, thresholds indicating the beginning of heat stress were found at THI values of 75 , 72 , and 72 for milk, protein, and fat yield, respectively (Bernabucci et al., 2014). Mean daily THI was lower to 75 THI during about $50 \%$ of summer days investigated, whereas THI was lower to the value of 72 , which is the threshold indicated for fat and protein yield, for only 2 to $3 \mathrm{~d}$ during summer (Figure 2C). Furthermore, during summer, 3 heat waves (a period of at least 3 consecutive days during which recovery hours, with THI values below 72, were less than 10; Hahn and Mader, 1997) were detected. In spring, the average mean daily THI was $64.7 \pm 3.9$ (mean and SD) and the average maximum daily THI was $69.4 \pm 3.8$.

The average values of chemical and nutritive characteristics of the diets for each season are shown in Table 2. The chemical and nutritive characteristics of the diet were almost constant throughout the seasons. Only CP has shown a relative variability, with grater values in the winter and spring seasons.

Average MY was (means and SD) $35.7 \pm 8.7,39.7$ \pm 8.0 , and $37.9 \pm 8.0 \mathrm{~L} \cdot$ animal $^{-1}$ per $\mathrm{d}$ in winter, spring, and summer, respectively. For all the main milk
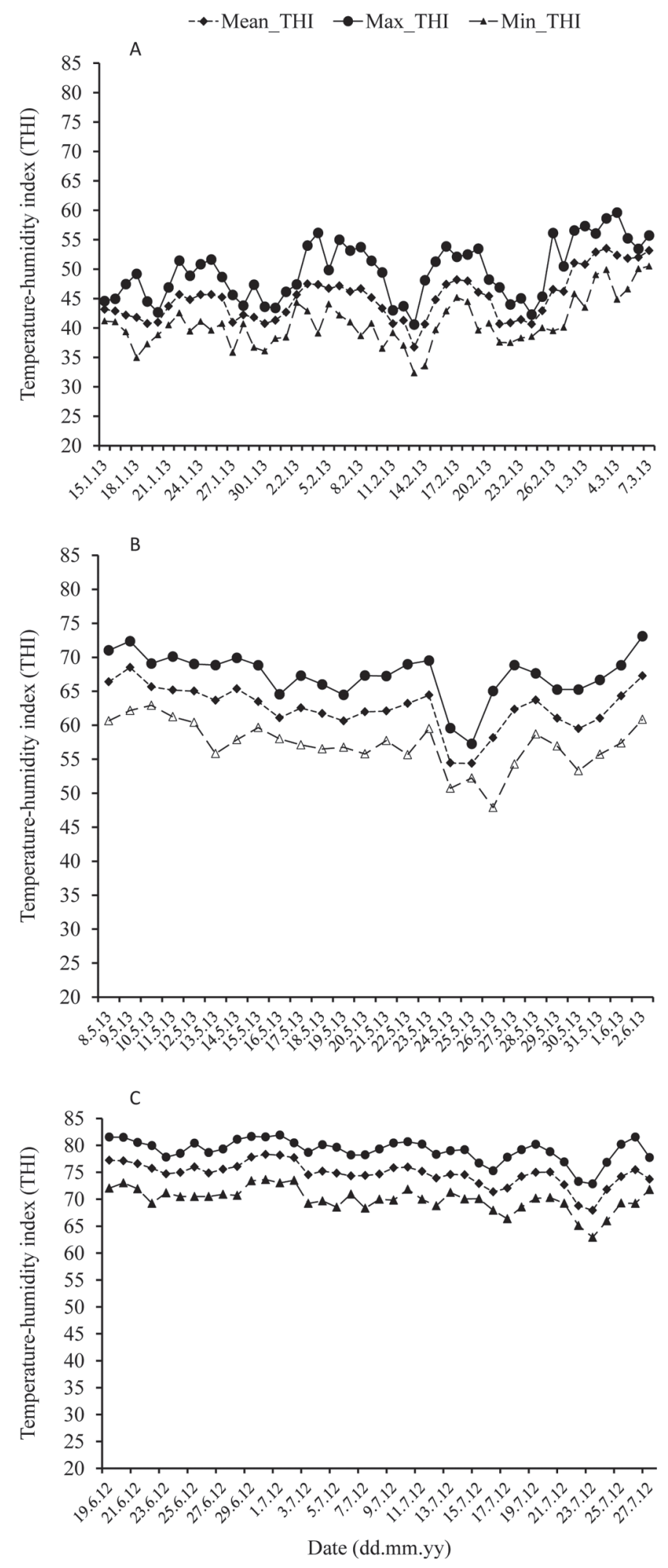

Figure 2. Microclimate conditions of barn during the experimental period: (A) winter, (B) spring, and (C) summer. 
Table 2. Chemical analysis and nutritive value of diets fed to cows during winter, spring, and summer season $(\text { mean } \pm \mathrm{SD})^{1}$

\begin{tabular}{lccc}
\hline Item & Winter & Spring & \multicolumn{1}{c}{ Summer } \\
\hline $\mathrm{DM}, \%$ & $51.48 \pm 2.00$ & $52.66 \pm 0.65$ & $52.42 \pm 1.88$ \\
$\mathrm{CP}, \%$ of DM & $18.11 \pm 0.97^{*}$ & $17.50 \pm 1.11$ & $15.74 \pm 0.66$ \\
Ash, \% of DM & $6.57 \pm 0.26$ & $5.64 \pm 0.16$ & $5.96 \pm 0.61$ \\
Crude fiber, \% of DM & $18.36 \pm 1.55$ & $16.88 \pm 1.03$ & $17.10 \pm 1.30$ \\
NDF, \% of DM & $31.70 \pm 0.51$ & $31.25 \pm 0.91$ & $32.29 \pm 1.61$ \\
Starch, \% of DM & $28.14 \pm 1.09$ & $31.49 \pm 0.46^{*}$ & $28.27 \pm 0.73$ \\
\hline
\end{tabular}

${ }^{1}$ On average, the mineral and vitamin supplementation was (per animal per day): $93.3 \mathrm{~g}$ of $\mathrm{Ca}, 16.0 \mathrm{~g}$ of $\mathrm{P}, 20$ $\mathrm{g}$ of $\mathrm{Mg}, 62 \mathrm{~g}$ of Na, $81 \mathrm{mg}$ of I (KI); $1,027 \mathrm{mg}$ of $\mathrm{Mn}(\mathrm{MnO}) ; 100 \mathrm{mg}$ of $\mathrm{Cu}\left(\mathrm{CuSO}_{4} \cdot 5 \mathrm{H}_{2} \mathrm{O}\right) ; 2,013 \mathrm{mg}$ of $\mathrm{Zn}$ $\left(\mathrm{ZnSO}_{4} \cdot \mathrm{H}_{2} \mathrm{O}\right.$ and $\left.\mathrm{ZnO}\right) ; 4.5 \mathrm{mg}$ of $\mathrm{Se}\left(\mathrm{Na}_{2} \mathrm{SeO}_{3}\right) ; 500,000 \mathrm{IU}$ of vitamin $\mathrm{A} ; 55,000 \mathrm{IU}$ of vitamin $\mathrm{D}_{3}$; and 1,100 $\mathrm{mg}$ of vitamin $\mathrm{E}$ acetate ( $\alpha$-tocopheryl acetate).

*Asterisks indicate significant differences from the value observed in the summer season $(P<0.05)$.

components (total solids, SNF, fat, and proteins), the lowest values were observed in summer season and the greatest in winter; intermediate values were observed in spring. Among the main milk components, only lactose did not change throughout the seasons (Table 3). Total solids in summer were $5.3 \%$ lower $(P=0.010)$ than in the winter and were $3.5 \%$ lower $(P=0.020)$ than in the spring. Similarly, fat percentage in summer was $15.8 \%$ lower $(P=0.001)$ than in the winter and was $11.1 \%$ lower $(P=0.011)$ than in the spring. Solidsnot-fat percentage was $2.8 \%$ lower during summer $(P$ $=0.012$ ) than in the winter, and was only numerically lower $(1.7 \%$ lower $)$ than in the spring. Similarly protein percentage in summer was $6 \%$ lower $(P=0.070)$ than in the winter, and was $3.2 \%$ lower $(P=0.049)$ than in the spring.

A mild effect of season $(P=0.070)$ was observed for milk SCC (Table 3), with greater values in summer $\left(151,000\right.$ cells $\left.\cdot \mathrm{mL}^{-1}\right)$ than in the winter $(72,000$ cells $\left.\cdot \mathrm{mL}^{-1}\right)$ and in the spring $\left(69,000\right.$ cells $\left.\cdot \mathrm{mL}^{-1}\right)$. The percentage of milk samples with SCC greater than 400,000 cells $\cdot \mathrm{mL}^{-1}$ was $25 \%$ in the summer and $10 \%$ in the winter and spring, respectively.
A worsening of MCP was observed in summer season (Table 3). In this season, the milk was characterized by a longer RCT to begin coagulation after the addition of the clotting enzyme. Also the $\mathrm{k}_{20}$ worsened in summer season compared with winter and spring, with a numerically longer time to reach a curd firmness of $20 \mathrm{~mm}$ in summer season. Furthermore, $a_{30}$ tended to be lower in summer compared with winter and spring $(P=0.071$ and $P=0.079$, respectively). The percentage of milk samples with scarce or very bad reactivity (milk with RCT longer than 27 min or milk that did not coagulate after $31 \mathrm{~min})$ was greater in summer $(25 \%)$ than in the winter $(12 \%)$ and spring (15\%). The percentage of milk samples having good coagulation properties was lower in summer $(17 \%)$ than in the winter $(48 \%)$ and in the spring (48\%).

Casein concentration, with the exception of $\gamma-\mathrm{CN}$, showed the lowest values in the summer season and the greatest values in the winter; intermediate values were observed in spring (Table 4). The concentration of $\alpha_{\mathrm{S}}-\mathrm{CN}$ in milk during summer was $22.6 \%$ lower $(P$ $=0.0001)$ than in the winter and was $16 \%$ lower $(P$ $=0.009)$ than in the spring. Also the concentration of

Table 3. Milk characteristics observed in winter, spring, and summer season

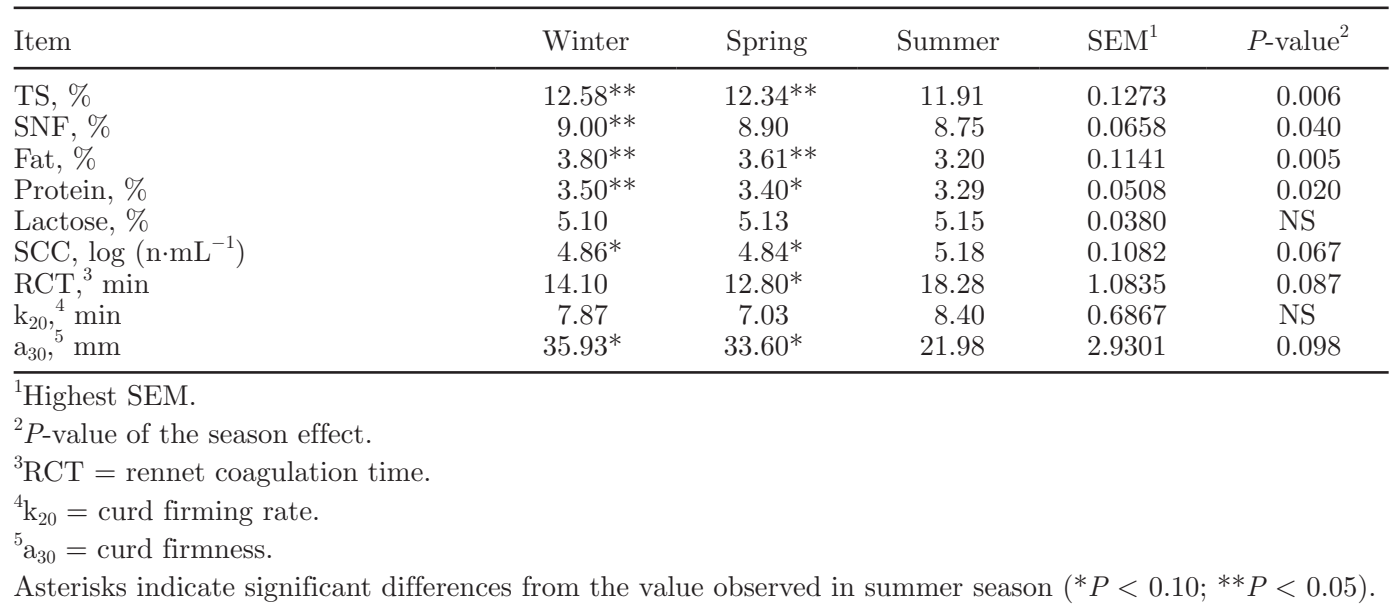


Table 4. Casein concentration in milk samples collected in winter, spring, and summer season

\begin{tabular}{|c|c|c|c|c|c|}
\hline Item & Winter & Spring & Summer & $\mathrm{SEM}^{1}$ & $P$ value ${ }^{2}$ \\
\hline \multicolumn{6}{|l|}{ Total CN } \\
\hline$g \cdot \mathrm{L}^{-1}$ & $27.50^{* *}$ & $24.84^{*}$ & 22.65 & 1.0715 & 0.0018 \\
\hline $\mathrm{g}$ per $100 \mathrm{~g}$ of protein & $76.67^{* *}$ & $76.55^{* *}$ & 74.29 & 0.9747 & 0.0400 \\
\hline \multicolumn{6}{|l|}{$\alpha_{S}-C N$} \\
\hline$g \cdot L^{-1}$ & $12.80^{* *}$ & $11.81^{* *}$ & 9.91 & 0.5489 & 0.0004 \\
\hline \multicolumn{6}{|l|}{$\beta-\mathrm{CN}$} \\
\hline $\mathrm{g} \cdot \mathrm{L}^{-1}$ & $9.78^{* *}$ & 8.54 & 7.89 & 0.4098 & 0.0013 \\
\hline $\mathrm{g}$ per $100 \mathrm{~g}$ of $\mathrm{CN}$ & 35.85 & 34.69 & 34.78 & 0.9086 & NS \\
\hline \multicolumn{6}{|l|}{ к-CN } \\
\hline$g \cdot \mathrm{L}^{-1}$ & $4.11^{*}$ & 3.73 & 3.69 & 0.1999 & 0.0985 \\
\hline $\mathrm{g}$ per $100 \mathrm{~g}$ of $\mathrm{CN}$ & $14.90^{*}$ & $14.97^{*}$ & 16.31 & 0.5204 & 0.0190 \\
\hline \multicolumn{6}{|l|}{$\gamma-\mathrm{CN}$} \\
\hline $\mathrm{g} \cdot \mathrm{L}^{-1}$ & $0.80^{* *}$ & $0.76^{* *}$ & 1.21 & 0.1776 & 0.0216 \\
\hline $\mathrm{g}$ per $100 \mathrm{~g}$ of $\mathrm{CN}$ & $2.90^{*}$ & $3.06^{*}$ & 5.32 & 0.7312 & 0.0007 \\
\hline
\end{tabular}

$\beta-\mathrm{CN}$ in milk during summer was $19.3 \%$ lower $(P=$ $0.003)$ than in the winter and was $7.7 \%$ numerically lower than in the spring. The differences for $\kappa-\mathrm{CN}$ among seasons were more attenuated, with $9.7 \%$ lower concentration of $\kappa-\mathrm{CN}$ in milk during summer than in the winter $(P=0.060)$. Conversely, the $\gamma$-CN concentration in milk was greater during summer, and in this season was $51 \%$ greater than in the winter $(P=0.030)$ and was $59 \%$ greater than in the spring. The effect of season on the $\mathrm{CN}$ fractions was also significant when the data were processed using the model covaried on $\mathrm{SCC}$, with the exception of k-CN for which the inclusion of SCC was not significant.

A seasonal effect on $\mathrm{CN}$ fractions expressed as a percentage of total $\mathrm{CN}$ was observed. The percentage of $\alpha_{\mathrm{S}} \mathrm{CN}$ on total $\mathrm{CN}$ observed in summer was $5.8 \%$ lower $(P=0.011)$ than in the winter and was $7.7 \%$ lower $(P=0.003)$ than in the spring. Conversely, the percentage of $\gamma$-CN on total $\mathrm{CN}$ observed in summer was $83 \%$ greater $(P=0.002)$ than in the winter and was $74 \%$ greater $(P=0.009)$ than in the spring. Also, the percentage of $\kappa-\mathrm{CN}$ on total $\mathrm{CN}$ observed in summer was $9.5 \%$ greater than in the winter and in the spring $(P=0.015$ and $P=0.033$, respectively). From the statistical analysis, using the model covaried on SCC, the seasonal effect on $\alpha_{S^{-}} \mathrm{CN}$ and $\gamma$-CN was still significant; conversely, the seasonal effect on $\kappa-\mathrm{CN}$ was not significant when the data were covaried on SCC. Furthermore, the relative proportion of $\mathrm{CN}$ fractions expressed on total protein was $74.3,76.7$, and $76.5 \%$ in the summer, winter, and spring, respectively.

A seasonal effect on all whey proteins fractions was observed (Table 5). The concentration of $\alpha$-LA was greatest in summer and lowest in the winter season. Conversely, $\beta-L G$ showed the lowest values in sum- mer and the greatest in the winter season. Both these whey proteins showed intermediate values in the spring season. From the statistical analysis, using the model covaried on SCC, the seasonal effect was still significant only for $\alpha$-LA. The content of IgG was greater in summer than in the winter and spring $(P=0.049$ and $P$ $=0.003$, respectively). Similar trend was observed for BSA, with greater values in summer than in the winter and spring $(P=0.069$ and $P=0.058$, respectively).

The main results from the $\mathrm{PC}$ analysis on milk characteristics have shown that PC1 and PC2 explained only the 22.2 and $19.2 \%$ of the total variance, respectively. Figure 3A shows the loading plot of $\mathrm{PC} 1$ versus PC2. Total solids, SNF, protein, $\mathrm{CN}$, and $\mathrm{a}_{30}$ mainly determined the increase of $\mathrm{PC} 1$. The reduction of $\mathrm{PC} 1$ was mainly determined by an increase of $\alpha-\mathrm{LA}$, BSA, IgG, $\gamma$-CN (expressed both in $\mathrm{g} \cdot \mathrm{L}^{-1}$ and as a percentage of $\mathrm{CN}$ ), RCT, and $\mathrm{k}_{20}$. The increase of $\mathrm{PC} 2$ was mainly associated with greater $\kappa-\mathrm{CN}$ and $\alpha_{\mathrm{S}}-\mathrm{CN}$ concentration, and greater $\beta-\mathrm{CN}$ as percentage of $\mathrm{CN}$. The PC1 separated the milk samples collected in summer from those collected in winter and spring (Figure 3B). Season distribution was mainly obtained along the PC1 axis, which was able to describe only the $22.2 \%$ of the total variance. Plotting $\mathrm{PC} 2$ against $\mathrm{PC} 1$, the summer season was scored in one zone of the plane, and the winter and spring season were on the opposite side.

\section{DISCUSSION}

\section{Main Milk Components}

Milk yield and milk characteristics may show changes over time as a result of the influence of the seasons on animals. Among the main causes of these variations can 
Table 5. Whey protein fraction in milk samples collected in winter, spring, and summer season

\begin{tabular}{|c|c|c|c|c|c|}
\hline Item & Winter & Spring & Summer & SEM $^{1}$ & $P$-value ${ }^{2}$ \\
\hline \multicolumn{6}{|l|}{$\alpha-\mathrm{LA}$} \\
\hline$g \cdot L^{-1}$ & $1.73^{* *}$ & $1.67^{* *}$ & 2.09 & 0.1204 & 0.0082 \\
\hline g per100 g of whey protein & $20.94^{* *}$ & $22.17^{* *}$ & 27.29 & 1.0201 & $<0.0001$ \\
\hline \multicolumn{6}{|l|}{$\beta-L G$} \\
\hline$g \cdot \mathrm{L}^{-1}$ & $5.85^{* *}$ & 5.29 & 4.73 & 0.2824 & 0.0050 \\
\hline $\begin{array}{l}\text { g per } 100 \mathrm{~g} \text { of whey protein } \\
\text { BSA }\end{array}$ & $69.58^{* *}$ & $68.72^{*}$ & 60.76 & 1.4465 & $<0.0001$ \\
\hline \multicolumn{6}{|l|}{ BSA } \\
\hline $\mathrm{g}$ per $100 \mathrm{~g}$ of whey protein & $4.70^{* *}$ & $5.00^{*}$ & 6.22 & 0.5719 & 0.0570 \\
\hline \multicolumn{6}{|l|}{$\mathrm{IgG}$} \\
\hline $\mathrm{g} \cdot \mathrm{L}^{-1}$ & $0.25^{* *}$ & $0.17^{* *}$ & 0.32 & 0.0378 & 0.0091 \\
\hline $\mathrm{g}$ per $100 \mathrm{~g}$ of whey protein & $2.96^{* *}$ & $2.28^{* *}$ & 4.12 & 0.4176 & 0.0030 \\
\hline \multicolumn{6}{|l|}{ Lactoferrin } \\
\hline$g \cdot \mathrm{L}^{-1}$ & $0.15^{* *}$ & 0.14 & 0.12 & 0.0096 & 0.0502 \\
\hline $\mathrm{g}$ per $100 \mathrm{~g}$ of whey protein & $1.82^{*}$ & $1.83^{*}$ & 1.61 & 0.1190 & 0.2166 \\
\hline
\end{tabular}

be included dietary factors, in particular the characteristics of feeds, as well as the feeding techniques, housing factors, and the climatic conditions (microclimatic) of the area where the animals are raised. The dietary factors play a major role in some conditions such as cows kept inside and fed silage during winter, and kept on pasture and fed fresh grass during spring-summer. These considerable differences in diets may influence chemical and physical characteristics of milk. In the current study, the cows were raised indoors and the diet was based on the same feeds throughout the seasons. Consequently, it could be hypothesized only a negligible and marginal effect of dietary factors on the changes of milk characteristics observed throughout the seasons.

The climatic issue could be considered the main factor that has affected the changes of milk characteristics throughout the seasons in this study. Po valley, where this study was carried out, is characterized by high temperature and high relative humidity during summertime, causing heat stress in dairy cows, with negative effects on milk characteristics (Bernabucci and Calamari, 1998; Bertocchi et al., 2014) and milk cheese-making properties (Calamari and Mariani, 1998). During the summer in the current study, the mean daily THI was $<75$ for about $50 \%$ of the summer days investigated, whereas it was $<72$ for only 2 to $3 \mathrm{~d}$. Therefore, according to Bernabucci et al., (2014), cows were subjected to mild-high heat stress during the summer season when our measurements were carried out.

In the current study, the lower concentration of fat and protein in milk were observed in summer and the greater concentration were observed in winter; intermediate values were observed in spring. Reduction of fat and protein concentration and MY as temperature increases has been reported (Casati et al., 1998; Ber- tocchi et al., 2014). Casati et al. (1998), in a research carried out in Piacenza province (Po valley) studying the season effect on individual MY and characteristics, observed a reduction of milk fat and protein concentration at mean daily temperature above $14^{\circ} \mathrm{C}$ and at mean daily THI above 55. Bertocchi et al. (2014), in a retrospective study on seasonal variations carried out on bulk milk collected from farms in the Lombardia region (Po valley), observed a negative correlation between THI and fat and protein concentration, and evidenced breakpoints (that represent an inflection point in the relationship between the independent and dependent variable) in the pattern at 50.2 and 65.2 maximum THI, respectively. In the current study, for many days of the spring season the mean daily THI ranged between 62 to 67 and the maximum daily THI ranged from 67 to 76 . These values are in the range or above the breakpoints reported before.

Casati et al. (1998) observed that milk fat and protein content decreased in spring and increased in autumn, and suggested that these changes were also related to the photoperiod and variation in MY, as also suggested by Bertocchi et al. (2014). Similarly, Aharoni et al. (2002), in a study carried out on Georgian and Israeli primiparous and Israeli multiparous dairy cows, observed greater fat and protein concentration from October to January, followed by an initial drop in spring and a significant reduction in summer.

In dairy cattle, photoperiod involves a series of hormonal changes, which might affect milk production, DMI, feeding behavior, reproduction, and growth (Dahl et al., 2000). Milk yield is in fact affected by photoperiod and increases as day length increases. Dahl et al. (2000) observed that an increase of daily light length from 12 to $16 \mathrm{~h}$ increased the MY of $2.5 \mathrm{~kg} \cdot$ animal $^{-1}$ 
A)

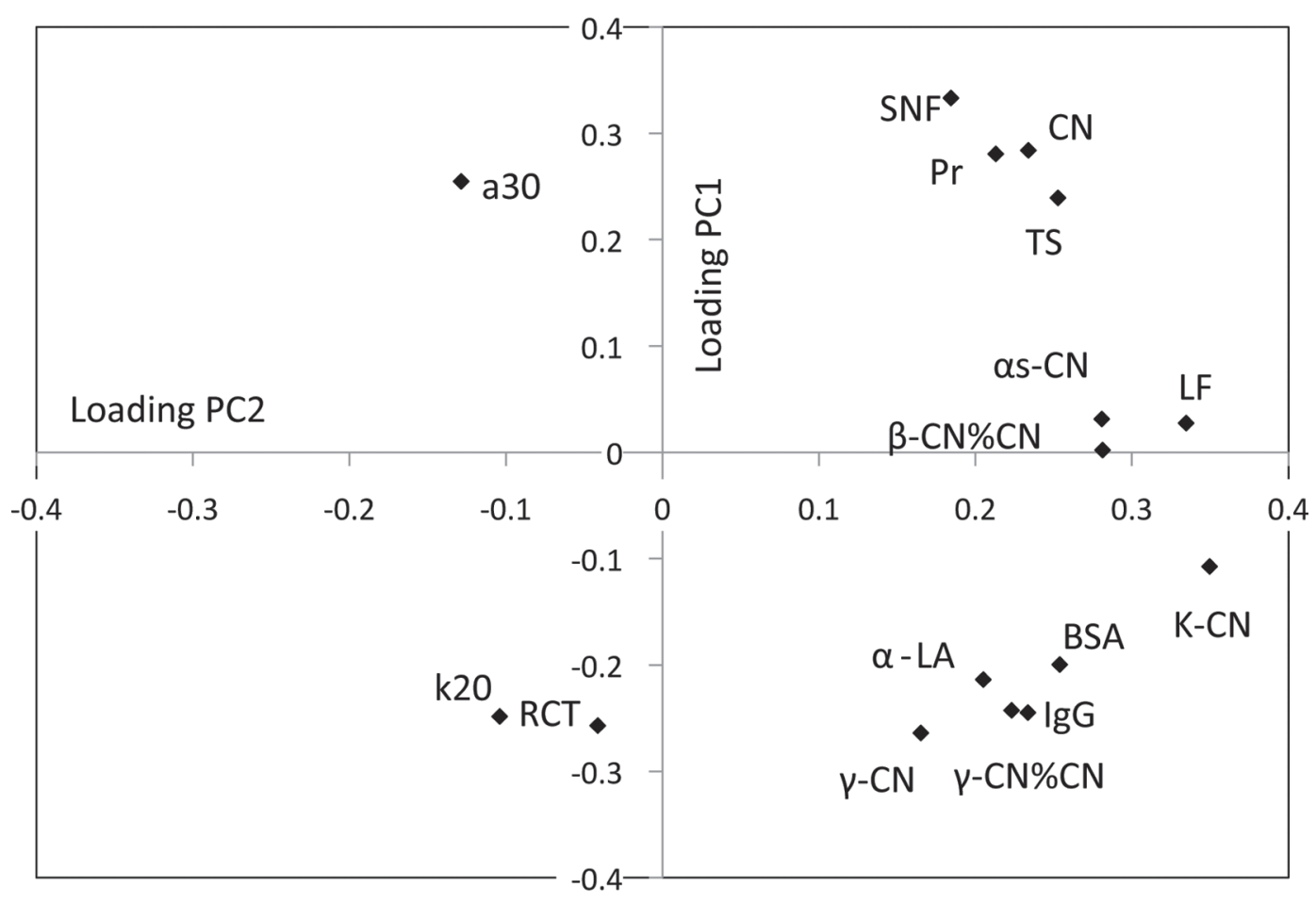

B)

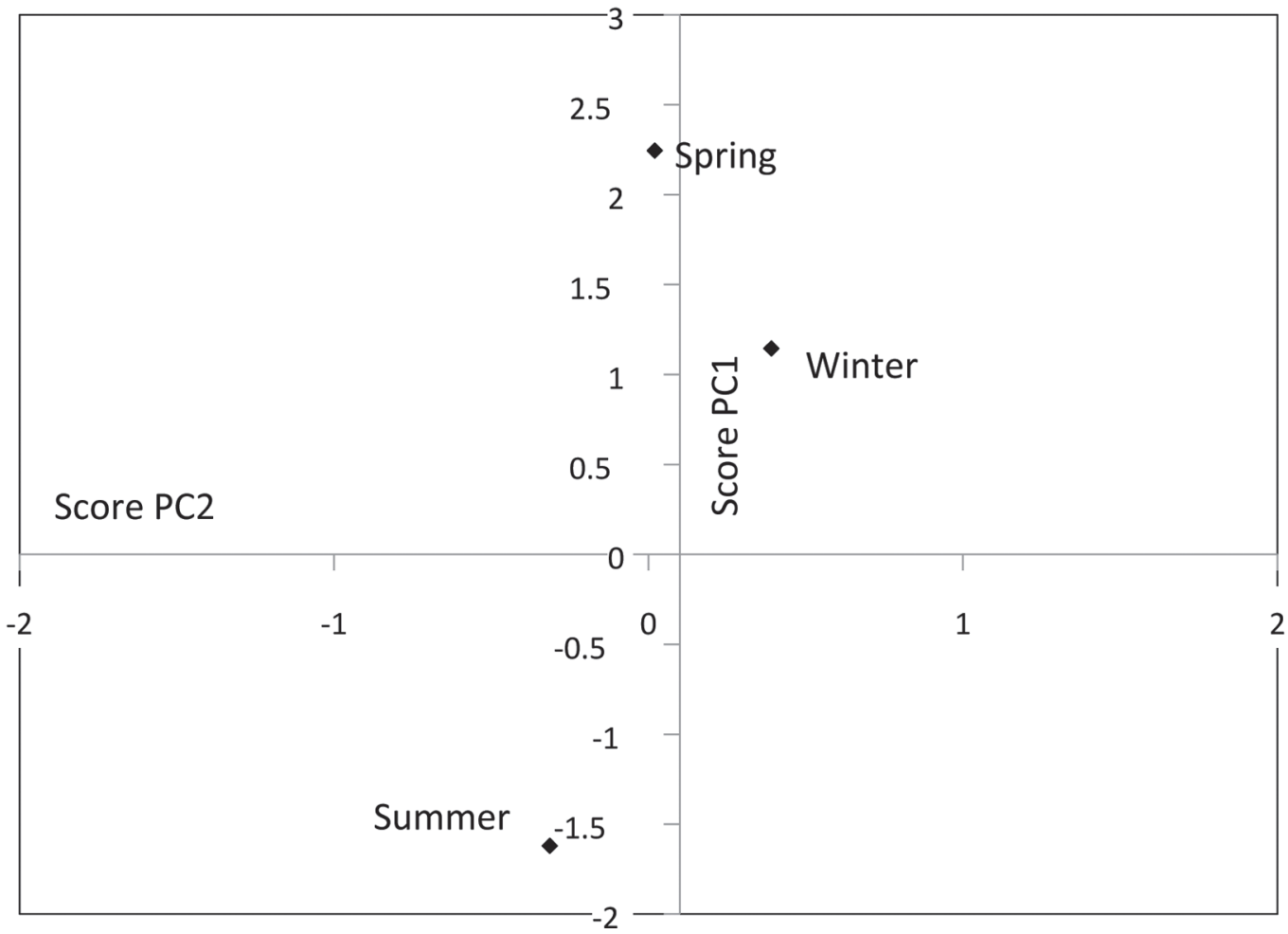

Figure 3. (A) Loading plot of the first 2 principal components ( $\mathrm{PC} 1$ and $\mathrm{PC} 2) . \mathrm{RCT}=$ rennet coagulation time; $\mathrm{k}_{20}=$ curd firming rate; $\mathrm{a}_{30}$ = curd firmness. (B) Score plot of PC-analyzed samples collected through season using PC1 and PC2. The PC1 and PC2 accounted for 41.4\% of the observed variation in the data. 
per d. Similarly, Calamari et al. (2002) observed that an increase of daily light length from 10 to $16 \mathrm{~h}$ increased the MY of $2.73 \mathrm{~kg} \cdot$ animal $^{-1}$ per d, with a concomitant reduction in protein concentration. Auldist et al. (2007) observed in melatonin-treated cows a reduction of prolactin in plasma, a drop in MY of $23 \%$, a reduction of lactose concentration, and an increase of fat, protein, and $\mathrm{CN}$ concentration in milk. Therefore, it is plausible that the reduction in milk components recorded in spring might be related to the photoperiod effect and in particular to the increase in MY as a response to the increasing photoperiod, with a consequent dilution effect on protein and fat concentrations. On this regard, Calamari et al. (2002) observed that only the $38 \%$ of MY change were responsible for milk protein dilution. In the current study, the average MY in spring was greater than winter (39.7 and. $35.7 \mathrm{~L} \cdot$ animal $^{-1}$ per $\mathrm{d}$ in spring and winter, respectively). Therefore, it is reasonable that the reduction of fat and protein in spring observed in this study was affected by the photoperiod, in part as a consequence of increased MY with a dilution effect (Bertocchi et al., 2014). Furthermore, the broad decrease in fat and protein content observed during the summer seems mainly related to the negative effect of hot conditions on the synthesis of these milk components.

\section{CN Fractions}

In this study, milk protein quantification was performed using SDS-PAGE, a standardized semiquantitative method, that is very useful for comparing different samples on a single gel, but it also has certain limitations, as broad peaks may sometimes result in overlap and degradation products other than the major $\gamma-\mathrm{CN}$, were not be quantified. $\gamma$-Caseins mainly result from postsecretory hydrolysis of $\beta-\mathrm{CN}$. The current study showed a reduction of $\mathrm{CN}$ and a profound change in the $\mathrm{CN}$ fractions during the summer season. The main cause of $\mathrm{CN}$ reduction during the summer was the reduction in $\alpha_{S^{-}} \mathrm{CN}$ and $\beta$-CN, and only the $\alpha_{S^{-}} \mathrm{CN}$ was lower in summer compared with winter and spring both as expressed as absolute $\left(\mathrm{g} \cdot \mathrm{L}^{-1}\right)$ and relative (percentage of total $\mathrm{CN}$ ) value. These results confirm those obtained by Bernabucci et al. (2002) in a research carried out on dairy cows monitored in spring and summer in a commercial dairy herd in Central Italy, in this case the concentration of protein fractions was measured by electrophoresis on cellulose acetate. Gellrich et al. (2014) recently observed seasonal effect on $\alpha-\mathrm{CN}$ and $\beta-\mathrm{CN}$, with higher $\beta-\mathrm{CN}$ as a percentage of protein in summer season. In this last paper, major milk protein analyses were conducted using a microfluidic electrophoresis and no data were presented on climatic condi- tions; thus it is not possible to adequately compare the present with the Gellrich et al. study.

The $\alpha_{S^{-}} \mathrm{CN}$ and $\beta$-CN contain high numbers of phosphate groups (Schmidt, 1980), and the phosphorylation of CN needs the presence of the $\gamma$-phosphate of ATP (Mercier and Gaye, 1983). During heat stress, the reduction in energy intake and the increased maintenance costs cause negative energy balance (Bernabucci et al., 2010). Consequently, we can hypothesize that the lower content of $\alpha_{S}-\mathrm{CN}$ and $\beta-\mathrm{CN}$ in summer milk might be partially due to the reduction in energy and protein availability, which usually occurs during heat stress (Abeni et al., 2007; Bernabucci et al., 2010; Calamari et al., 2013).

Despite marked reductions in nutrient intake, heatstressed cattle exhibit increased basal insulin levels and stimulated insulin response (Baumgard and Rhoads, 2012). The effect of heat stress on muscle and mammary protein metabolism is unclear because insulin typically stimulates protein synthesis in both tissues (Bernabucci et al., 2010). In heat-stressed cows, the circulating nonesterified fatty acid levels are reduced (Abeni et al., 2007), and the adipose tissue is less sensitive to catabolic signals during heat stress (Baumgard and Rhoads, 2012). It seems that acclimation to heat stress conditions increases a shift toward carbohydrate use (Rhoads et al., 2013), increasing the use of glucose as energy source, decreasing the oxidation of NEFA, and the plasma glucose concentration tended to be lower (Abeni et al., 2007). In addition to lipid and glucose metabolism, protein metabolism is also altered under heat stress conditions (Bernabucci et al., 2010). These metabolic alterations occur coincident with increased circulating basal and stimulated plasma insulin concentrations (Rhoads et al., 2013), influencing MY and milk protein synthesis, in particular with $\mathrm{CN}$ fractions more phosphorylated and probably more influenced by energy status.

Recently, Han et al. (2011) observed in vitro study on mammary epithelial cells that heat stress decreased the mRNA level of milk proteins, in particular $\alpha-C N$ and $\beta-\mathrm{CN}$, and suggested that heat shock induced the stress responses of bovine mammary epithelial cells, with a strong effect on the secretion of protein and fat concentration in milk, and increased the tolerance of the cell itself. Thus, heat stress has direct (tissue hyperthermia) and indirect (reduced feed intake) effects, both of which may affect milk protein synthesis in the mammary gland. Furthermore, the metabolic alterations triggered by hot conditions are also implied.

In the current study, $\kappa$-CN decreased in summer when expressed as an absolute value $\left(\mathrm{g} \cdot \mathrm{L}^{-1}\right)$; conversely, the relative percentage of $\kappa$-CN was greater in summer. These results confirm those obtained by Bernabucci 
et al. (2002). In contrast, Kroeker et al. (1985), in a research carried out analyzing by urea PAGE CN fractions throughout the year, did not observe a definite seasonal trend for the relative percentage of $\mathrm{CN}$ fractions. Those authors observed that the relative proportions of $\mathrm{CN}(\beta-\mathrm{CN}$ and $\kappa-\mathrm{CN})$ were more affected by SCC in the milk. In particular, the relative percentage of $\mathrm{k}$-CN increased with increasing SCC; conversely, the relative percentage of $\beta$ - $\mathrm{CN}$ decreased dramatically with increasing SCC. In the present study, the relative proportion of $\mathrm{k}-\mathrm{CN}$ did not differ significantly in summer compared with the other seasons when the data were covaried on SCC, and differences between season for $\alpha_{\mathrm{s}}-\mathrm{CN}$ and $\gamma-\mathrm{CN}$ were still significant when SCC was included as covariate into the model. Taking into account all results, it could be hypothesized that the synthesis of $\alpha_{\mathrm{S}}-\mathrm{CN}$ and $\beta-\mathrm{CN}$ in the mammary gland are more negatively affected by hot conditions, and that the increased percentage of $\kappa-\mathrm{CN}$ is mainly a consequence of a greater reduction of $\alpha_{S^{-}} \mathrm{CN}$ and $\beta-\mathrm{CN}$ synthesis and, in a lesser extent, of a greater breakdown of $\beta$-CN. Moreover, differences in results of CN relative percentage may in part be due to the separation method used.

\section{Whey and Serum Protein Fractions}

In this study the concentrations of $\alpha$-LA were greater during summer season compared with the other seasons. The literature contains little information on changes of whey proteins during the hot summer months. Bernabucci et al. (2002) did not observe any difference for $\alpha-L A$ and $\beta-L G$ between seasons. Gellrich et al. (2014), in a research carried out in Germany studying the effect of season, observed greater $\alpha$-LA concentration in summer compared with the fall season. Similarly, Brodziak et al. (2012) found a significantly higher concentration of $\alpha-\mathrm{LA}$ and a higher ratio of $\alpha-\mathrm{CN}$ : $\beta-\mathrm{CN}$ in milk of cows from the spring-summer season, in comparison with the fall-winter period. In heat-stressed cows, the reduction of energy intake and the increased maintenance costs causes often negative energy balance (Bernabucci et al., 2010 ), and the increased $\alpha$-LA observed in hot conditions does not seem related to the impairment of energy balance.

The insulin infusion plus glucose to minimize blood glucose changes increased MY and the proportions of $\alpha$-LA and $\beta$-LG (Mackle et al., 1999). Glucagon infusion decreased the synthesis of $\alpha-\mathrm{LA}$ as well as of $\beta-\mathrm{LG}$, with a reduction in the relative percentage of $\alpha$-LA but not of $\beta$-LG. Similarly, atropine injection, which reduces plasma amino acids and plasma insulin concentration, tends to decrease the concentrations of $\alpha$-LA in milk (Auldist et al., 2003). In heat-stressed cows, the basal insulin is increased, and it seems involved in the increased $\alpha$-LA observed in milk. However, also considering that bST injection preferentially increases $\alpha$-LA synthesis (Eppard et al., 1985), the endocrinological changes commonly observed in heat-stressed cows are controversial on the expected $\alpha$-LA changes in milk.

A greater BSA concentration in milk was observed in this study during summer compared with the other seasons. Serum albumin enters in milk via the paracellular route throughout loosening tight junction or in association with neutrophil diapedesis (or both), not necessarily under damage of lactocytes. An increase of milk BSA was observed during intramammary infection (Shuster et al., 1991). In the current study, SCC were low and only slight greater values in summer compared with the other seasons was observed. Furthermore, the greater BSA in summer was still significant when the data were covaried on SCC. Then, we can exclude mastitis as the possible and main cause of greater BSA in milk during summer season.

Lu et al. (2003), in research carried out in Holstein cows under humid tropical summer climates, observed greater BSA in milk of summer cows, at the same time the SCC remained below $5 \times 10^{5}$ cells per $\mathrm{mL}$, but $\mathrm{N}$-acetyl-glucosaminidase increased linearly with the progress of summer season ( $\mathrm{Lu}$ et al., 2003). $\mathrm{N}$ Acetyl-glucosaminidase activity in milk is considered as a direct indicator of secretory cell damage. Steady increase of N-acetyl-glucosaminidase activity in milk could mean a gradual deterioration of mammary epithelial barrier under the summer climates of the Lu et al. (2003) study. Those authors concluded that gradual regression of mammary gland occurred along the humid tropical summer season. The increased BSA observed in our study could be due also to the alteration of the mammary epithelial barrier.

\section{Milk Coagulation Properties}

The milk produced during summer period by cows raised in unfavorable climatic conditions, shows a worsening in the main cheesemaking characteristics, in particular a worsening of MCP (Calamari and Mariani, 1998; Malacarne et al., 2005). In the current study, a higher percentage of milk samples with scarce or very bad reactivity, as well as a lower percentage of milk samples having good coagulation properties was observed in summer.

The results obtained with the $\mathrm{PC}$ analysis have shown that plotting PC1 and PC2, the summer season was confined in one zone of the plane, and the winter and spring seasons were on the opposite side. The discrimination of summer was mainly related to the milk solids (negative relationship with total solids, 
$\mathrm{SNF}$, protein, and $\mathrm{CN}$ concentration), together with the MCP (positive relationship with RCT and curd firming rate, and negative relationship with curd firmness). These results confirm the relationship between CN content and MCP (Calamari and Mariani, 1998; Bertoni et al., 2001, 2005). Furthermore, the discrimination of summer season was also related to the effect of BSA and $\gamma$-CN (positive relationship), but the effect of SCC was negligible and did not contribute to the discrimination among seasons. These results indicate that the increase of these protein fractions during summer was not related to the only slight increase of SCC and that the worsening of MCP during summer was also a consequence of these milk protein fraction changes.

In this study, the $\kappa$-CN concentration was lower in summer milk, but the relative percentage of this CN fraction slightly increased in the summer season. Better MCP was observed in milk with higher $\kappa-\mathrm{CN}$ concentration (Marziali and Ng-Kwai-Hang, 1986). Wedholm et al. (2006) observed that poorly and noncoagulating samples were associated with a low concentration of $\kappa-\mathrm{CN}$ and a low relative proportion of $\kappa-\mathrm{CN}$. Mariani et al. (1998) observed that a greater availability of $\kappa$-CN per unit of $\alpha_{\mathrm{S}^{-}} \mathrm{CN}$ would lead to a configuration such as to be more favorable from the viewpoint of coagulation properties: improved enzymatic reactivity of the micelles and increased capacity of aggregation of paraCN. It should be noted, however, that small differences in the fraction of $\kappa$-CN could induce significant changes in the attitude to clot: the $1 \%$ more or less of $\kappa-\mathrm{CN}$ implies a $20 \%$ change in the diameter of the micelles. Higher values of $\mathrm{k}$-CN micelles are associated with smaller (Laurent et al., 1992) and therefore more suitable for the coagulation. It should be also considered that an increase in either total $\kappa-\mathrm{CN}$ concentration or relative percentage of $\kappa-\mathrm{CN}$ (percentage of total $\mathrm{CN}$ ) in general decreases overall levels or relative percentage of $\alpha_{\mathrm{S}^{-}} \mathrm{CN}$ and $\alpha_{\mathrm{S} 2}-\mathrm{CN}$, affecting milk coagulation through the effect on $\mathrm{pH}$ (Bittante et al., 2012). All these findings seem to indicate that in the summer season the concentration of $\kappa-\mathrm{CN}$ in milk, and in particular its relative proportion, does not appear among the main and direct factors that negatively affect the MCP.

In the current study, a lower $\alpha_{\mathrm{S}} \mathrm{CN}$ and $\beta$-CN concentration was observed in summer milk, and only the former was also lower as a relative proportion. Contents and relative percentage of $\alpha_{S^{-}} \mathrm{CN}$ and $\beta-\mathrm{CN}$, due to their high sensitivity toward precipitation by calcium ions, strongly influence milk coagulation properties (Schmidt, 1980). The effects of these fractions on the MCP are controversial. Remeuf and Hurtaud (1991) observed that high values of $\beta-\mathrm{CN}$ and low of $\alpha_{\mathrm{S} 1}-\mathrm{CN}$ are favorable for coagulation, in particular for clotting time. According to Pearse and Mackinlay (1989), $\beta-C N$ play an essential role in syneresis. Grandison et al. (1984) found positive relationships between coagulum strength and $\alpha_{S}-\mathrm{CN}$ and $\beta-\mathrm{CN}$ concentrations. Conversely, Jõudu et al. (2008) observed that milk formed a firmer curd when the relative proportion of $\mathrm{a}_{\mathrm{S1}}-\mathrm{CN}$ and $\beta-\mathrm{CN}$ in total $\mathrm{CN}$ was lower.

The $\alpha_{S^{-}} \mathrm{CN}$ and $\beta-\mathrm{CN}$, rich in phosphate groups, are the 2 acidic components of the CN micelles (Schmidt, 1980). Thus, the lower contents of $\alpha_{S^{-}} \mathrm{CN}$ and $\beta-\mathrm{CN}$ of milk yielded during the summer might explain the higher milk $\mathrm{pH}$ and the lower milk titratable acidity commonly registered during the hot summer months (Calamari and Mariani, 1998). The clotting time is heavily influenced by $\mathrm{pH}$ and titratable acidity of milk, and also curd firmness is greatly affected by milk acidity (Bittante et al., 2012). Our results seem to indicate that the worsening of MCP observed in summer could have been promoted by the reduction of the concentration and relative proportion of $\alpha_{S^{-}} \mathrm{CN}$ and $\beta-\mathrm{CN}$, involving consequences on $\mathrm{pH}$ and titratable acidity.

\section{CONCLUSIONS}

The reduction of milk protein concentration during hot conditions in summer season seems to be mainly attributable to the reduction in $\mathrm{CN}$ concentration. The $\alpha_{\mathrm{S}^{-}} \mathrm{CN}$ and $\beta-\mathrm{CN}$ are the $\mathrm{CN}$ fractions most sensitive to hot conditions. The $\mathrm{CN}$ composition changes throughout seasons, with a reduction of the proportion of $\alpha_{S^{-}} \mathrm{CN}$ and $\beta-\mathrm{CN}$ and an increase of the proportion of $\kappa-\mathrm{CN}$ and $\gamma-\mathrm{CN}$ during summer. The worsening of the MCP observed during summer seems mainly attributable to the reduction of protein concentration and changes in milk protein fractions. Besides the increase of the protein fractions related to the increased proteolysis during the hot season, a change also occurred throughout the seasons in the proportion of protein fractions obtained with electrophoresis and expressed as a percentage of total protein $(\mathrm{N} \times 6.38)$ concentration in milk. This increase of undefined proteins observed only during summer needs to be deeply investigated for a better understanding of the relationships between milk protein fractions and MCP in the summer season.

\section{ACKNOWLEDGMENTS}

This project was financially supported by the Italian Ministry of Agriculture, Food and Forestry (MiPAAF), FILIGRANA project (D.M. 25741/7303/11-01/12/ 2011). The authors thank Matteo Festa, owner of the dairy farm where the study was carried out. 


\section{REFERENCES}

Abeni, F., L. Calamari, and L. Stefanini. 2007. Metabolic conditions of lactating Friesian cows during hot season in Po valley. 1. Blood indicators of heat stress. Int. J. Biometeorol. 52:87-96.

Aharoni, Y., O. Ravagnolo, and I. Misztal. 2002. Comparison of lactational responses of dairy cows in Georgia and Israel to heat load and photoperiod. Anim. Sci. 75:469-476.

Auldist, M. J., C. M. Menzies, and C. G. Prosser. 2003. Effects of atropine on plasma amino acid profiles and on the synthesis of individual milk proteins in dairy cows fed with pasture. J. Dairy Res. 70:373-378.

Auldist, M. J., S. A. Turner, C. D. McMahon, and C. G. Prosser 2007. Effects of melatonin on the yield and composition of milk from grazing dairy cows in New Zealand. J. Dairy Res. 74:52-57.

Baumgard, L. H., and R. P. Rhoads. 2012. Ruminant nutrition symposium: ruminant production and metabolic responses to heat stress. J. Anim. Sci. 90:1855-1865.

Bernabucci, U., S. Biffani, L. Buggiotti, A. Vitali, N. Lacetera, and A. Nardone. 2014. The effects of heat stress in Italian Holstein dairy cattle. J. Dairy Sci. 97:471-486.

Bernabucci, U., and L. Calamari. 1998. Effects of heat stress on bovine milk yield and composition. Zootech. Nutr. Anim. 24:247-258.

Bernabucci, U., N. Lacetera, L. H. Baumgard, R. P. Rhoads, B. Ronchi, and A. Nardone. 2010. Metabolic and hormonal acclimation to heat stress in domesticated ruminants. Animal 4:1167-1183.

Bernabucci, U., N. Lacetera, B. Ronchi, and A. Nardone. 2002. Effects of hot season on milk protein fractions in dairy cows. Anim. Res. $51: 25-33$

Bertocchi, L., A. Vitali, N. Lacetera, A. Nardone, G. Varisco, and U. Bernabucci. 2014. Seasonal variations in the composition of Holstein cow's milk and temperature-humidity index relationship. Animal 8:667-674.

Bertoni, G., L. Calamari, G. Maianti, and B. Battistotti. 2005. Milk for protected denomination of origin (PDO) cheeses: I. The main required features. Pages 217-228 in Indicators of milk and beef quality. J. F. Hocquette and S. Gigli, ed. EAAP Pubblication No. 112, Wageningen Academic Publishers, Wageningen, the Netherlands.

Bertoni, G., L. Calamari, and M. G. Maianti. 2001. Producing specific milk for speciality cheeses. Proc. Nutr. Soc. 60:231-246.

Bittante, G., M. Penasa, and A. Cecchinato. 2012. Invited review: Genetics and modeling of milk coagulation properties. J. Dairy Sci. 95:6843-6870.

Brodziak, A., J. Barlowska, J. Kròl, and Z. Litwińczuk. 2012. Effect of breed and feeding system on content of selected whey proteins in cow's milk in spring-summer and autumn-winter seasons. Ann. Anim. Sci. 12:261-269.

Calamari, L., M. G. Maianti, and A. Azzoni. 2002. Effetti del fotoperiodo sulla produzione e su alcune caratteristiche del latte di bovine Frisone. Sci. Tecn. Latt. Cas. 53:189-206.

Calamari, L., and P. Mariani. 1998. Effects of the hot environment conditions on the main milk cheesemaking properties. Zootec. Nutr. Anim. 24:259-271.

Calamari, L., F. Petrera, L. Stefanini, and F. Abeni. 2013. Effects of different feeding time and frequency on metabolic conditions and milk production in heat stressed dairy cows. Int. J. Biometeorol. 57:785-796.

Casati, M. R., V. Cappa, L. Calamari, F. Calegari, and G. Folli. 1998. Influenza delle stagioni sulla produzione e su talune caratteristiche del latte bovino. Sci. Tecn. Latt. Cas. 49:7-25.

Dahl, G. E., B. A. Buchanan, and H. A. Tucker. 2000. Photoperiodic effects on dairy cattle: A review. J. Dairy Sci. 83:885-893.

Eppard, P. J., D. E. Bauman, J. Bitman, D. L. Wood, R. M. Akers, and W. A. House. 1985. Effect of dose of bovine growth hormone on milk composition: $\alpha$-Lactalbumin, fatty acids, and mineral elements. J. Dairy Sci. 68:3047-3054.

Gellrich, K., H. H. D. Meyer, and S. Wiedemann. 2014. Composition of major proteins in cow milk differing in mean protein concentration during the first 155 days of lactation and the influence of season as well as short-term restricted feeding in early and midlactation. Czech J. Anim. Sci. 59:97-106.

Giacinti, G., L. Basiricò, B. Ronchi, and U. Bernabucci. 2013. Lactoferrin concentration in buffalo milk. Ital. J. Anim. Sci. 12:139-143.

Grandison, A. S., G. D. Ford, D. Millard, and A. J. Owen. 1984. Chemical composition and coagulating properties of renneted milks from cows during early lactation. J. Dairy Res. 51:407-416.

Hahn, G. L., and T. L. Mader. 1997. Heat waves in relation to thermoregulation, feeding behavior and mortality of feedlot cattle. Pages 563-571 in Proc. 5th Int. Livest. Environ. Symp. (Vol. I). ASAE SP-01-97. American Society Agricultural Engineers, St. Joseph, MI

Han, H., W. JiaQi, L. FaDi, B. DengPan, Z. LinYun, and C. RuiLian. 2011. Responses of cultured bovine mammary epithelial cells to heat stress. J. Agric. Biotechnol. 19:287-293.

Ingraham, R. H., R. W. Stanley, and W. C. Wagner. 1979. Seasonal effects of tropical climate on shaded and nonshaded cows as measured by rectal temperature, adrenal cortex hormones, thyroid hormone, and milk production. Am. J. Vet. Res. 40:1792-1797.

Intergovernmental Panel on Climate Change. 2007. The Intergovernmental Panel on Climate Change 4th Assessment Report (IPCC: AR4). http://www.ipcc.ch/publications_and_data/publications_ and_data_reports.htm\#2.

Jõudu, I., M. Henno, T. Kaart, T. Püssa, and O. Kärt. 2008. The effect of milk protein contents on the rennet coagulation properties of milk from individual dairy cows. Int. Dairy J. 18:964-967.

Kadzere, C. T., M. R. Murphy, N. Silanikove, and E. Maltz. 2002. Heat stress in lactating dairy cows: A review. Livest. Prod. Sci. 77:59-91.

Kroeker, E. M., F. Ng-Kway-Hang, J. F. Hayes, and J. E. Moxley. 1985. Effects of environmental and milk protein polymorphism on composition of casein fraction in bovine milk. J. Dairy Sci. $68: 1752-1757$

Laurent, F., D. Coomans, J. N. Gardeur, and B. Vignon. 1992. Composition azotée et caractéristiques technologiques du lait de vache en relation avec la nature et le niveau d'apport de l'aliment concentré. Lait 72:175-183.

Lu, C. H., C. J. Chang, P. N. Lee, C. P. Wu, M. T. Chen, and X. Zhao, 2003. Functional characterization of mammary gland of Holstein cows under humid tropical summer climates. Asian-australas. J. Anim. Sci. 16:988-995.

Mackle, T. R., A. M. Bryant, S. F. Petch, J. P. Hill, and M. J. Auldist. 1999. Nutritional influences on the composition of milk from cows of different protein phenotypes in New Zealand. J. Dairy Sci. $82: 172-180$.

Malacarne, M., S. Fieni, F. Tosi, P. Franceschi, P. Formaggioni, and A. Summer. 2005. Seasonal variations of the rennet-coagulation properties of herd milks in Parmigiano-Reggiano cheese manufacture: Comparison between Italian Friesian and Italian Brown cattle breeds. Ital. J. Anim. Sci. 4(Suppl. 2):242-244.

Mariani, P., A. Summer, M. Franchetti, P. Vecchia, and E. Fossa. 1998. Ripartizione percentuale delle caseine in latti di massa delle vacche di razza Frisona, Bruna, Reggiana e Modenese. Sci. Tecn. Latt. Cas. 49:181-192.

Marziali, A. S., and K. F. Ng-Kwai-Hang. 1986. Effects of milk composition and genetic polymorphism on coagulation properties of milk. J. Dairy Sci. 69:1793-1798.

Mercier, J. C., and P. Gaye. 1983. Milk protein synthesis. Pages 177230 in Biochemistry of Lactation. T. B. Mepham, ed. Elsevier Science Publisher B.V., Amsterdam, the Netherlands.

Nardone, A., B. Ronchi, N. Lacetera, M. S. Ranieri, and U. Bernabucci. 2010. Effects of climate changes on animal production and sustainability of livestock systems. Livest. Sci. 130:57-69.

Pearse, M. J., and A. G. Mackinlay. 1989. Biochemical aspect of syneresis: A review. J. Dairy Sci. 72:1401-1407.

Remeuf, F., and C. Hurtaud. 1991. [Liaisons entre les caracteristiques physico-chimiques des laits et leur aptitude fromagere]. Pages 15 26 in Proc. Qualité des laits a la production et aptitude fromagère. M. Journet and A. Holden, ed. INRA-ENSA, Rennes, France. 
Rhoads, R. P., L. H. Baumgard, J. K. Suagee, and S. R. Sanders. 2013. Nutritional interventions to alleviate the negative consequences of heat stress. Adv. Nutr. 4:267-276.

Schmidt, D. G. 1980. Colloidal aspects of casein. Neth. Milk Dairy J. $34: 42-64$

Segnalini, M., U. Bernabucci, A. Vitali, A. Nardone, and N. Lacetera. 2013. Temperature humidity index scenarios in the Mediterranean basin. Int. J. Biometeorol. 57:451-458.
Shuster, D. E., R. J. Harmon, J. A. Jackson, and R. W. Hemken. 1991. Suppression of milk production during endotoxininduced mastitis. J. Dairy Sci. 74:3763-3774.

Wedholm, A., L. B. Larsen, H. Lindmark-Mansson, A. H. Karlsson, and A. Andren. 2006. Effect of protein composition on the cheesemaking properties of milk from individual dairy cows. J. Dairy Sci. 89:3296-3305. 